University of Michigan Law School

University of Michigan Law School Scholarship Repository

Articles

Faculty Scholarship

2004

\title{
Bridging the North/South Divide: International Redistribution and Tax Competition
}

Reuven S. Avi-Yonah

University of Michigan Law School, aviyonah@umich.edu

Available at: https://repository.law.umich.edu/articles/46

Follow this and additional works at: https://repository.law.umich.edu/articles

Part of the International Law Commons, Taxation-Transnational Commons, Tax Law Commons, and the Transnational Law Commons

\section{Recommended Citation}

Avi-Yonah, Reuven S. "Bridging the North/South Divide: International Redistribution and Tax Competition." Mich. J. Int'l L. 26, no. 1 (2004): 371-87.

This Article is brought to you for free and open access by the Faculty Scholarship at University of Michigan Law School Scholarship Repository. It has been accepted for inclusion in Articles by an authorized administrator of University of Michigan Law School Scholarship Repository. For more information, please contact mlaw.repository@umich.edu. 


\title{
BRIDGING THE NORTH/SOUTH DIVIDE: INTERNATIONAL REDISTRIBUTION AND TAX COMPETITION
}

\author{
Reuven S. Avi-Yonah*
}

I. INTRODUCTION

II. INTERNATIONAL TAX COMPETITION AND THE TAXATION OF CAPITAL

III. Tax Competition and Developing Countries

IV. What Can Be Done About Tax Competition? .................. 382

V. CONCLUSION

\section{INTRODUCTION}

The most important social problem facing humanity at the beginning of the 21 st century is the yawning divide in standards of living between the rich nations of the global North and the poor nations of the global South. The following table gives some indicia of the current gap in living standards. It shows that the majority of the population in most developing countries lives on less than two dollars a day; that in some developing countries, over a quarter of children aged 10-14 are employed in the work force; that mortality for children under five in developing countries can be ten to fifteen times as high as in developed countries; that over half the population in many developing countries lacks access to safe drinking water or sanitation; and that illiteracy rates among 15-24 year olds can be as high as $40 \%$ for males and $60 \%$ for females.

The persistence of such gaps is unacceptable. The North-South divide lies at the heart of the rich world's current troubles, including terrorism, immigration pressures, and environmental threats (such as global warming or threats to biodiversity). None of these issues can be adequately addressed without taking measures to bridge the divide, and to bring the South up to a level where it can cooperate with the North.

An agenda to begin bridging the divide already exists. All 191 members of the United Nations have pledged themselves to achieve eight goals (the "Millennium Development Goals," or MDGs) by 2015:

1. Reduce by half the proportion of people living on less than a dollar a day, and who suffer from hunger;

* Irwin I. Cohn Professor of Law, The University of Michigan. 
2. Ensure that all boys and girls complete a full course of primary education;

3. Eliminate gender disparity in primary and secondary education;

4. Reduce by $2 / 3$ the mortality rate of children under five;

5. Reduce maternal mortality rates by $3 / 4$;

6. Halt and begin to reverse the spread of HIV, malaria, and other major diseases;

7. Reduce by half the proportion of people without access to safe drinking water, and ensure environmental sustainability; and

8. Develop a global partnership for development.'

The UN has estimated that achieving the MDGs would require an additional $\$ 50$ billion per year in aid to developing countries from now until $2015 .{ }^{2}$ Unfortunately, current projections show that this relatively small sum (less than $2 \%$ of the U.S. Federal budget) cannot be obtained, and achievement of the MDGs by 2015 is uncertain. ${ }^{3}$

The key problem is the reluctance of people in rich democracies to support foreign aid. Most rich countries provide less than $1 \%$ of their total budget to aid poor countries, and many (including the United States) provide much less. Moreover, even this meager aid is highly unpopular: most opinion surveys in the United States show that Americans both overestimate by a factor of over a hundred how much aid is given, and would favor eliminating all foreign aid. In addition, most of the aid that is given is governed by political considerations, rather than by where it would produce the best results (for example, a very high percentage of total U.S. aid is given to Israel and Egypt under the 1977 Camp David accords).

It is possible to argue that given the link between the North-South divide and problems facing the North, such as terrorism and immigration pressures, it is shortsighted for the people of the North to oppose foreign aid. There are, however, four arguments to the contrary. First, even achieving the MDGs will not bridge the divide; the problems will persist. To really bridge the divide would require an unacceptable level of

1. United Nations Millennium Development Goals Website, at http://www.un.org/ millenniumgoals.

2. Implementation of the United Nations Millennium Declaration, Report of the Secretary General, at 19, U.N. Doc. A/59/282 (2004), available at http://ods-dds-ny.un.org/doc/ UNDOC/GEN/N04/465/40/PDF/N0446540.pdf. [hereinafter Secretary General's Report].

3. See id. 


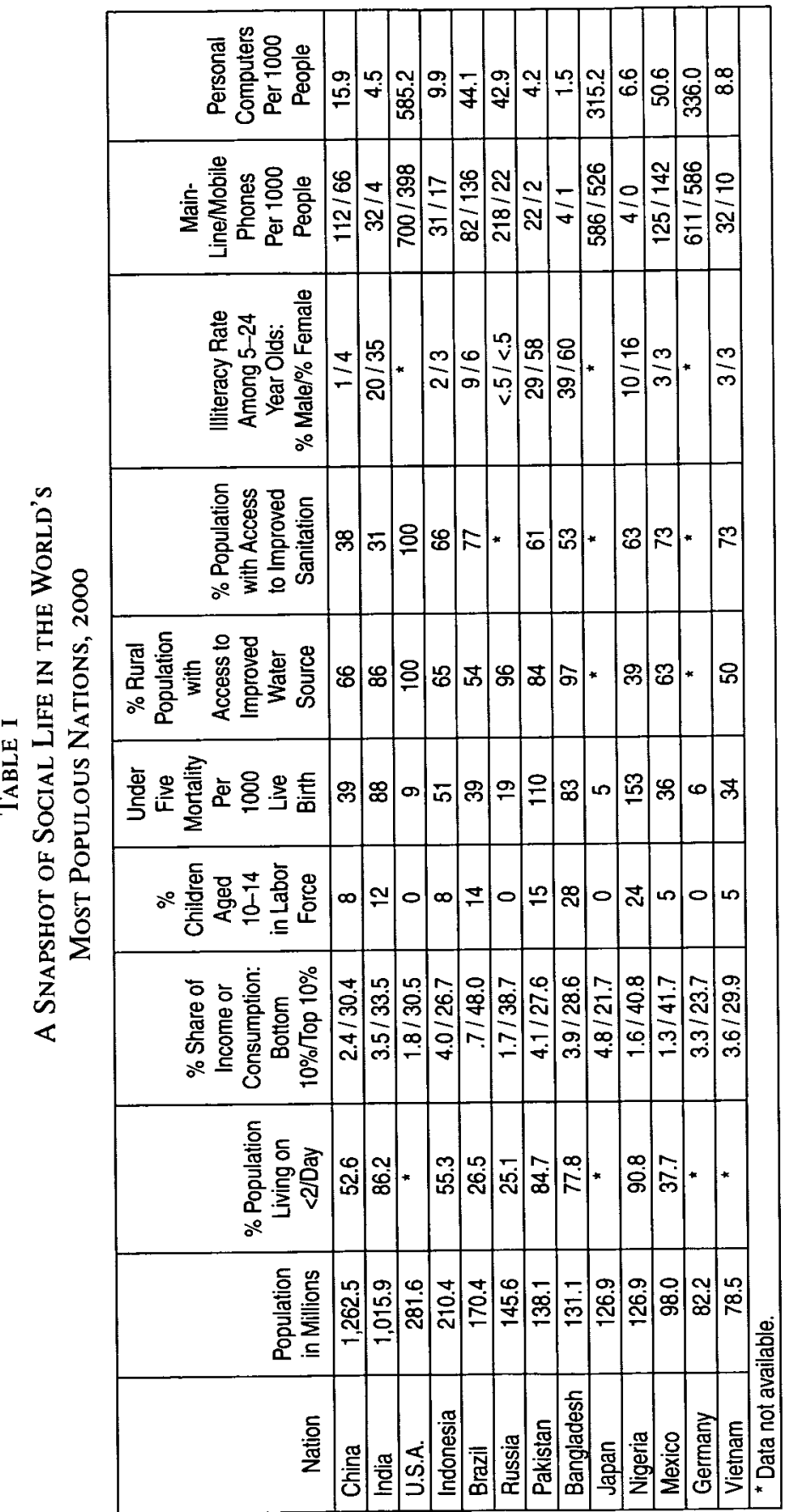


redistribution: Joel Slemrod and his colleagues have estimated that to achieve the same level of redistribution internationally as is currently achieved by the U.S. tax system domestically, over $60 \%$ of the world's population would be on welfare, and tax rates on the remaining $40 \%$ would more than triple. ${ }^{4}$ Second, the notion that "the poor of your own community come first" has a very strong hold, and most people are likely to continue supporting local causes before they support aid to foreigners. Third, there is the concern that foreign aid is simply wasted, or worse, lines the pockets of corrupt foreign officials. In the absence of adequate international supervision of aid distribution, this is a difficult argument to counter. Finally, even if people are misguided in their opposition to foreign aid, in a democracy the people govern, and their wishes, rather than the wishes of the elite, should dictate the use of tax money.

Thus, an increase in official aid to the level required by the MDGs is not in the cards. For the same reason, proposals to levy some kind of tax on the North in order to fund development in the South, like the Tobin Tax on currency exchanges, or a tax on computer bits, seem unlikely to be implemented, since voters in the North would not approve of them, for the same reasons they disapprove of foreign aid.

Can anything be done, then, to help the South achieve the MDGs? It seems to me that the key is to help the developing countries help themselves, and the key to that is to identify issues in which opposition between the North and the South stems more from the influence of "special interests" in the North than from opposition by the people of the North as a whole. That is, the key is to identify issues on which the prodevelopment position would prevail if brought to a democratic vote in the North. One good example of such an issue seems to be trade in agricultural goods and textiles, in which the majority in rich countries would benefit if tariff barriers and subsidies were reduced. This issue is addressed elsewhere in this volume, so I will not further belabor it here.

Another, similar issue is tax competition among developing countries, which costs them significant tax revenues, and benefits richcountry interests like multinational enterprises and the financial services sector. To understand this issue requires an overview of current developments in international taxation, as they relate to globalization.

In general, the current age of globalization can be distinguished from the previous one (from 1870 to 1914) by the much higher mobility of capital than of labor (in the previous age, before immigration restrictions, labor was at least as mobile as capital). This increased mobility has been the result of technological changes (the ability to move funds

4. Wojciech Kopczuk et al., The Limitations of Decentralized World Redistribution: An Optimal Taxation Approach, Eur. ECON. REv. (forthcoming). 
electronically), and the relaxation of exchange controls. The mobility of capital has led to tax competition, in which sovereign countries lower their tax rates on income earned by foreigners within their borders in order to attract both portfolio and direct investment. Tax competition, in turn, threatens to undermine the individual and corporate income taxes, which remain major sources of revenue (in terms of percentage of total revenue collected) for all modern states.

The response of both developed and developing countries to these developments has been first, to shift the tax burden from (mobile) capital to (less mobile) labor, and second, when further increased taxation of labor becomes politically and economically difficult, to cut government services. Thus, globalization and tax competition lead to a fiscal crisis for countries that wish to continue to provide services to their citizens, at the same time as demographic factors and the increased income inequality, job insecurity, and income volatility that result from globalization render such services more necessary.

This paper argues that if government service programs are to be maintained in the face of globalization, and if developing countries are to raise the funds needed to achieve the MDGs, it is necessary to cut the intermediate link by limiting tax competition. From both practical and normative considerations, however, any limits placed on tax competition should be congruent with maintaining the ability of democratic states to determine the size of their governments.

\section{INTERNATIONAL TAX COMPETITION AND THE TAXation OF CaPital}

From its beginnings late in the 19th century, the modern state has been financed primarily by progressive income taxation. The income tax differs from other forms of taxation (such as consumption or social security taxes) in that in theory it includes income from capital in the tax base, even if it is saved and not consumed. Because the rich save more than the poor, a tax that includes income from capital in its base is more progressive (taxes the rich more heavily) than a tax that excludes income from capital (e.g., a consumption tax or a payroll tax). The ability to tax saved income from capital (i.e., income not vulnerable to consumption taxes) is impaired, however, if the capital can be shifted overseas to jurisdictions where it escapes taxation.

Two recent developments have dramatically augmented the ability of both individuals and corporations to earn income overseas free of income taxation: the effective end of withholding taxation by developed 
countries, and the rise of production tax havens in developing countries. ${ }^{5}$ Since the United States abolished its withholding tax on interest paid to foreigners in 1984, no major capital-importing country has been able to impose such a tax, for fear of driving mobile capital elsewhere (or increasing the cost of capital for domestic borrowers, including the government itself). ${ }^{6}$ The result is that individuals can generally earn investment income free of host-country taxation in any of the world's major economies.' Moreover, even developed countries find it exceedingly difficult to effectively collect the tax on the foreign income of their individual residents in the absence of withholding taxes imposed by host countries, because the investments can be made through tax havens with strong bank secrecy laws. ${ }^{8}$ Developing countries, with much weaker tax administrations, find this task almost impossible. Thus, cross-border investment income can largely be earned free of either host or home country taxation. ${ }^{9}$

For example, consider a wealthy Mexican who wishes to earn taxfree interest income from investing in the bonds of an American corporation. All he needs to do is set up, for a nominal fee, a Cayman Islands corporation to hold the bonds. The interest payments are then made to the Caymans corporation without any U.S. tax withheld, under the socalled "portfolio interest exemption." income to the Mexican tax authorities, and they have no way of knowing that the Caymans corporation is effectively an "incorporated pocketbook" of the Mexican resident. Nor are the exchange of information provisions of the U.S.-Mexico tax treaty of any help, because the IRS has no way of knowing that the recipient of the interest payments is controlled by a Mexican resident, and therefore cannot report this to the Mexican authorities. As a result, the income is earned completely free of tax (the Caymans, of course, impose no income taxes of their own).

5. Reuven S. Avi-Yonah, Globalization, Tax Competition and the Fiscal Crisis of the Welfare State, 113 HARv. L. REv. 1573, 1576 (2000).

6. See generally Vito TANZI, TAXation In AN INTEgRating World (1995); Edward H. Gardner, Taxes on Capital Income in TAx HaRmonization IN THE EuROPEAN COMmUNITY 52 (George Kopits ed., 1992).

7. See Reuven Avi-Yonah \& Linda Swartz, Virtual Taxation: Source-Based Taxation in the Age of Derivatives, 2 Derivatives 247 (1997); Edmund S. Cohen, Individual International Tax Planning Employing Equity Derivatives, 4 Derivatives 52 (1996) (foreign residents may avoid host-country withholding tax through equity derivatives); Gregory May, Flying on Instruments: Synthetic Investments and Withholding Tax Avoidance, 73 TAX NoTES 1225 (1996).

8. TANZI, supra note 6.

9. Chander Kant, Foreign Direct Investment and Capital Flight, 80 Princeton STud. InT'L Fin. 1 (1989); Charles E. McLure, Jr., U.S. Tax Laws and Capital Flight from Latin America, 20 U. Miami InTER-Am. L. Rev. 321 (1989).

10. I.R.C. \& 871(h). 
When we switch our attention from passive to productive investment, a similar threat to the taxing capacity of both home and host jurisdictions emerges. In the last decade, competition for inbound investment has led an increasing number of countries (103, as of 1998) to offer tax holidays specifically geared to foreign corporate investors." Given the relative ease with which an integrated multinational can shift production facilities in response to tax rates, such "production tax havens" enable multinationals to derive most of their income abroad, free of host-country taxation. ${ }^{12}$ Moreover, most developed countries (including the United States) do not dare impose current taxation (or sometimes any taxation) on the foreign source business income of their resident multinationals, for fear of reducing the competitiveness of those multinationals against multinationals of other countries. ${ }^{13}$ If they did, new multinationals could be set up as residents of jurisdictions that do not tax such foreign source income. ${ }^{14}$ Thus, business income can also be earned abroad, largely free of either host- or home-country taxation.

For example, Intel Corporation, a top ten multinational, has operations in more than thirty countries around the globe. Specifically, outside the U.S., Intel has major manufacturing facilities in Puerto Rico, China, Malaysia, the Philippines, Ireland, and Israel. ${ }^{15}$ Outside the United States, all of Intel's manufacturing facilities are located in countries granting tax holidays. Nor does Intel pay current U.S. tax on its income from those foreign operations, because under U.S. law, active income earned by foreign subsidiaries of U.S. multinationals is not taxed until it is repatriated in the form of dividends, which Intel can delay for many years. ${ }^{16}$ Thus, the effective tax rate on Intel's foreign source income is far below the nominal U.S. corporate rate of $35 \%$.

If income from capital can escape the income tax net, the tax becomes, in effect, a tax on labor. Several empirical studies have in fact suggested that in some developed jurisdictions, the effective tax rate on income from capital approaches zero, and tax rates on capital have

11. Raymond Vernon, In the Hurricane's Eye: The Troubled Prospects of MULTINATIONAL ENTERPRISES (1998); UNCTAD, WORLD INVESTMENT REPORT 1996: Investment, Trade and International Policy ARRANgements (1996).

12. Rosanne Altshuler \& T. Scott Newlon, The Effects of U.S. Tax Policy on the Income Repatriation Patterns of U.S. Multinational Corporations, in StUdies In INTERNATIONAL TaXation 77 (Alberto Giovannini ed., 1993); James R. Hines, Jr. \& Eric M. Rice, Fiscal Paradise: Foreign Tax Havens and American Business, 109 QUARTERLY J. ECON. 149 (1994).

13. Robert J. Peroni, Back to the Future: A Path to Progressive Reform of U.S. International Income Tax Rules, 51 U. Miami L. Rev. 975 (1997).

14. James R. Hines, Jr., The Flight Paths of Migratory Corporations, 6 J. ACcT. AudirING \& FIN. 447 (1991).

15. See InTEl CoRP., 1999 ANNuAl Report (2000).

16. See generally Reuven S. Avi-Yonah, International Taxation of Electronic Commerce, 52 TAX L. REV. 507 (1997). 
tended to go down sharply since the early 1980s (when exchange controls were relaxed). ${ }^{17}$ As a result, countries that used to rely on the revenues from the income tax are forced to increase relatively regressive taxes. The two fastest-growing taxes in the Organisation for Economic Cooperation and Development (OECD) member countries in recent years have been consumption taxes (from 12\% of total revenues in 1965 to $18 \%$ in 1995) and payroll taxes (from $19 \%$ to $27 \%$ ), both of which are more regressive than the income tax. ${ }^{18}$ Over the same period, the personal and corporate income taxes have not grown as a percentage of total revenues (the personal income tax accounted for $26 \%$ of total revenues in 1965 and $27 \%$ in 1995, while the figures for the corporate income tax are $9 \%$ and $8 \%$, respectively). ${ }^{19}$ Total tax revenue as a percentage of GDP in developed countries went up sharply during the same period (from an average of $28 \%$ in 1965 to almost $40 \%$ in 1994), and this increase is largely accounted for by the rise of consumption and payroll taxes. ${ }^{20}$ Moreover, there is evidence that, as the degree of openness of an economy in OECD member countries increases, taxes on capital tend to go down, while taxes on labor go up (the income tax is imposed on both capital and labor, so that its stability may mask this trend). ${ }^{21}$

The same trends can be observed in developing countries as well. In non-OECD member countries (outside the Middle East), total government revenues as a share of GDP rose from an average of $18.8 \%$ in $1975-80$ to $20.1 \%$ in $1986-92{ }^{22}$ This growth was financed primarily by the growth of revenues from the VAT in the same period (from $25.5 \%$ of total revenues to $31.8 \%$ ). At the same time, revenues from both the individual and the corporate income tax were flat or declined. ${ }^{23}$

17. See OECD, Revenue Statistics 1965-2002 passim (2003); Dani RodriK, Has Globalization Gone Too Far? (1997).

18. See OECD, supra note 17, Part II.

19. Id. at 73.

20. Tax Policy Division, Fiscal Affairs Department, International Monetary Fund, TAX Policy HandBook (Parthasarathi Shome ed., 1995) [hereinafter IMF].

21. Enrique G. Mendoza et al., Effective Tax Rates in Macroeconomics: Cross-Country Estimates of Tax Rates on Factor Income and Consumption, 34 J. MONETARY ECON. 297 (1994); Enrique G. Mendoza et al., On the Ineffectiveness of Tax Policy in AlterING Long-Run Growth, (Centre of Econ. Pol'y Research, Discussion Paper No. 1378, 1996).

22. See IMF, supra note 20.

23. See id. 


\section{Tax Competition and Developing Countries}

The drawbacks of tax competition for developed countries are relatively clear, because such countries have an elaborate social insurance safety net that requires a high level of government expenditure which is threatened by tax competition. ${ }^{24}$ But how does tax competition affect developing countries?

First, it should be pointed out that developing countries need the revenues at least as much as developed countries do, if not more. A common misperception is that only OECD member countries are confronted by a fiscal crisis as a result of the increasing numbers of elderly people in the population. In fact, the increase in dependency ratios (the ratio of the elderly to the working population) is expected to take place in other geographic areas as well, as fertility rates go down and health care improves. ${ }^{25}$ Outside the OECD and the transition economies, the dependency ratio starts in the single digits in the 1990 s, but rises to just below $30 \%$ by $2100{ }^{26}$ Moreover, while outside the OECD and the transition economies direct spending on social insurance is much lower, other forms of government spending (e.g., government employment) effectively fulfill a social insurance role. In Latin America, for example, direct government spending on social insurance is much lower than indirect spending through government employment and procurement programs. ${ }^{27}$

Moreover, it seems strange to argue that developing countries need tax revenues less than developed countries because they have less developed social insurance programs. If one accepts the normative case for social insurance, it applies to developing countries with even greater force because of widespread poverty, which means that losing a job can have much direr consequences. ${ }^{28}$ The need for revenues in developing countries, however, goes far beyond social insurance. In some developing countries, revenues are needed to insure the very survival of organized government, as the Russian experience demonstrates. ${ }^{29}$ In other, more stable developing countries, revenues are needed primarily to provide for adequate education (investment in human capital), which

24. Willi Leibfritz et al., OECD Econ. Dep't, Ageing Populations, Pension Systems AND Government Budgets, (Working Paper No. 156, 1995) available at http:// www.oecd.org/dataoecd/33/8/1863020.pdf.

25. See generally Janet Stotsky, Payroll Taxes and the Funding of Social Security Systems in IMF, supra note 20, at 177.

26. Charles E. McLure, Jr., Tax Policies for the XXIst Century, 21st IFA Congress SEMINAR Series 9, 11 (1996).

27. K. Subbarao et al., World Bank, Safety Net Programs and Poverty ReDUCTION 93-101 (1997).

28. See UNDP, 1997 Human Development Report (1997).

29. Meltdown in Russia, Economist, Aug. 29, 1998, at 47. 
many regard as the key to promoting development. ${ }^{30}$ For example, the UN has estimated that for only an additional $\$ 50$ billion per year, all people in the world can obtain basic social services (such as elementary education). ${ }^{31}$ Given current trends in foreign aid, most of these funds have to come from developed country governments, ${ }^{32}$ and they are essential if the MDGs are to be reached by 2015 .

Second, the standard advice by economists to small open economies is that they should refrain from taxing foreign investors, because such investors cannot be made to bear the burden of any tax imposed by the capital importing country. ${ }^{33}$ Therefore, the tax will necessarily be shifted to less mobile factors in the host country, such as labor and land, and it is more efficient to tax those factors directly. While this argument seems quite valid as applied to portfolio investment, however, it seems less valid with regard to FDI, for two reasons. First, the standard advice does not apply if a foreign tax credit is available in the home country of the investor, which frequently would be the case for FDI. ${ }^{34}$ Second, the standard advice assumes that the host country is small. An extensive literature on multinationals suggests, however, that they typically exist in order to earn economic rents. ${ }^{35}$ In that case, the host country is no longer "small" in the economic sense. That is, there is a reason for the investor to be there and not elsewhere. Therefore, any tax imposed on such rents (as long as it is below 100\%) will not necessarily drive the investor to leave, even if it is unable to shift the burden of the tax to labor or landowners.

This argument clearly holds in the case of rents that are linked to a specific location, such as natural resources or a large market. ${ }^{36}$ But what if the rent can be earned in a large number of potential locations? In this case, the host country will not be able to tax the rent if the multinational can credibly threaten to go elsewhere, although once the investment has been made, the rent can be taxed. This situation, which is probably the

30. Amartya Sen, Development Thinking at the Beginning of the XXI Century, in Economic and Social Development in the XXI Century 531, 536 (Louis Emmerij ed., 1997).

31. See Secretary General's Report, supra note 2.

32. Report of the Secretary-General to the Preparatory Committee for The High-Level International Intergovernmental Event on Financing for Development, U.N. GAOR Preparator Comm., 2d Sess. at 4, U.N. Doc. A/AC.257/12 (2000).

33. See Assaf Razin \& Efraim Sadka, International Tax Competition and Gains from Tax Harmonization, 37 ECON. LETTERS 69 (1991).

34. Timo Viherkentta, Tax Incentives in Developing Countries and InternaTIONAL TAXATION 71 (1991).

35. Jean-Francois Hennart, The Transaction Cost Theory of the Multinational Enterprise, in The Nature of the Transnational Firm 81, 81-82 (Pitelis et al. eds., 1991).

36. See John H. Dunning, Explaining International Production (1988). 
most common, ${ }^{37}$ would require coordinated action to enable all host countries to tax the rent earned within their borders. Some possibilities for such action are described below.

This relates to the final argument, which is that host countries need to offer tax incentives to be competitive. An extensive literature has demonstrated that taxes do in fact play a crucial role in determining investment location decisions, ${ }^{38}$ but all of these studies emphasize that the tax incentives are crucial given the availability of such incentives elsewhere. ${ }^{39}$ Thus, it can be argued that given the need for tax revenues, developing countries would in general prefer to refrain from granting tax incentives, if only they could be assured that no other developing country would be able to grant such incentives. ${ }^{40}$

Thus, restricting the ability of developing countries to compete in granting tax incentives does not truly restrict their autonomy or counter their interests. This is the case whenever they grant the incentive only for fear of competition from other developing countries, and would not have granted it but for such fear. Whenever competition from other countries drives the tax incentive, eliminating the competition does not hurt the developing country, and may aid its revenue raising efforts (assuming it can attract investment on other grounds, which is typically the case). Moreover, under the proposals described below, developing countries remain free to lower their tax rates generally (as opposed to granting specific tax relief aimed at foreign investors).

Two additional points need to be made, from a developing country perspective. The first concerns the question of tax incidence. Since the tax competition that is most relevant to developing countries concerns the corporate income tax, it is important to attempt to assess the incidence of that tax in evaluating the effects of collecting it on the welfare of the developing country. Unfortunately, after decades of analysis, no consensus exists on the incidence of the corporate tax. While older studies have tended to conclude that the tax is borne by shareholders or by all capital providers, more recent studies have suggested that the tax is

37. See Hennart, supra note 35.

38. See Eric Bond, Tax Holidays and Industry Behavior, 63 Rev. Econ. \& STAT. 88 (1981); Michael J. Boskin \& William G. Gale, The Effects on Tax Policy on the International Location of Investment, in THE EFFECTS OF TAXATION ON CAPITAL ACCUMULATION 214 (Martin Feldstein ed., 1999); James R. Hines, Jr., Lessons from Behavioral Responses to International Taxation, 52 NAT'L TAX J. 305, 318-19 (1999).

39. Stephen E. Guisinger \& Assocs., Investment Incentives and Performance REQUIREMENTS (1985).

40. Reuven S. Avi-Yonah, Globalization, Tax Competition and the Fiscal Crisis of the Welfare State, 113 HARV. L. REv. 1575, 1645 (2000). 
borne to a significant extent by consumers or labor. ${ }^{41}$ Another possibility is that the tax on established corporations was borne by those who were shareholders at the time the tax was imposed or increased, because thereafter it is capitalized into the price of the shares. ${ }^{42}$ It is unlikely that this debate will be decided any time soon (in fact, the incidence may be shifting over time, especially as globalization may enable corporations to shift more of the tax burden to labor). From the perspective of a developing country deciding whether to collect taxes from a multinational, however, three out of the four possible alternatives for incidence (current shareholders or capital providers, old shareholders, and consumers) are largely the residents of other jurisdictions, and therefore from a national welfare perspective, the developing country gains by collecting the tax. Even if some of the tax is shifted to labor in the developing country, it can be argued that as a matter of tax administration, it is more efficient (as well as more politically acceptable) to collect the tax from the multinational than to attempt to collect it from the workers.

Finally, it should be noted that a developing country may want to collect taxes from multinationals even if in general it believes that the private sector is more efficient in using the resources than the public sector. That is because, in the case of a foreign multinational, the taxes that the developing country fails to collect may indeed be used by the private sector, but in another jurisdiction, and would therefore not benefit the developing country. One possible solution, which is in fact employed by developing countries, is to refrain from taxing multinationals while they re-invest domestically, but to tax them upon remittance of the profits abroad. Such taxation of dividends and other forms of remittance, however, is subject to the same tax competition problem that we discussed above. Thus, it would appear that overcoming the tax competition problem is in most cases in the interest of developing countries, and the question remains how to do so in the face of the collective action problem described above.

\section{What Can Be Done About Tax Competition?}

The tax competition problem is thus essentially a problem of coordination and trust. Each jurisdiction would prefer to tax investors from abroad to gain the revenue, but is afraid that by doing so it would drive the investors to other jurisdictions that do not tax them. If there was a

41. Joseph A. Pechman, Federal Tax Policy (1987); Dep't of the Treasury,

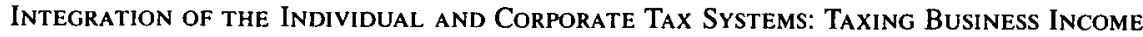
ONCE (1992).

42. See Pechman, supra note 41. 
way to coordinate actions among the relevant jurisdictions, they all could gain added revenues without running the risk of losing the investment.

A good illustration of how this dynamic works is the history of German taxation of interest income. In 1988, Germany introduced a 10\% withholding tax on interest paid to bank depositors, but had to abolish it within a few months because of the magnitude of capital flight to Luxembourg. In 1991, the German Federal Constitutional Court held that withholding taxes on wages but not on interest violated the constitutional right to equality. The government thereupon reintroduced the withholding tax on interest, but made in inapplicable to non-residents. ${ }^{43}$ Non-residents may, however, be Germans investing through Luxembourg bank accounts. To cope with this problem, the Germans have led an EU effort to introduce a $20 \%$ withholding tax on all interest payments to EU residents. ${ }^{44}$ In 2003 the EU adopted a "savings directive" that would provide for exchange of information (or in some cases a withholding tax) for payments to residents of member states, but it does not apply to payments to non-EU residents and it is conditioned on obtaining satisfactory exchange of information from Switzerland and the United States.

Thus, the key to finding a solution to the tax competition problem is to attack it on a broad multilateral basis, through an organization such as the OECD. Under current conditions, the OECD is the natural choice for leading such coordinated actions against tax competition, for three reasons. First, for individual investors to earn decent returns on their capital without incurring excessive risks, they need to invest in an OECD member country. Tax havens do not offer adequate investment opportunities, and developing countries are generally considered too risky for portfolio investment (other than through mutual funds, which do not offer tax avoidance opportunities). Thus, if all OECD members enforced taxation of portfolio investment, it could be subject to tax without requiring cooperation from the tax havens.

Second, about $85 \%$ of the world's multinationals are headquartered in OECD member countries. This is likely to continue to be the case for a while, because OECD members offer stable corporate and securities law protection to investors that is lacking in other countries. Thus, if all OECD members agreed on a coordinated basis to tax their multinationals currently on their income from abroad, most of the problem of tax competition from direct investment could be solved.

43. Leif Mutén, International Experience of How Taxes Influence the Movement of Private Capital, 8 TAX NoTES INT'L 743, 746 (1994).

44. See generally Conclusions of the ECOFIN Council Meeting on 1 December 1997 Concerning Taxation Policy, 1998 O.J. (C2) 2. 
Third, the OECD has the required expertise (its model tax treaty is the global standard) and has already started on the path of limiting tax competition. In 1998, it adopted a report entitled Harmful Tax Competition: An Emerging Global Issue. ${ }^{45}$ This report is somewhat limited, because it only addresses tax competition for financial activities and services (as opposed to, e.g., Intel's manufacturing plants). It also does not address the taxation of investment income. It does represent, however, an extremely useful first step, and proof that a consensus can be reached on the tax competition issue (Switzerland and Luxembourg abstained, but did not dare veto the adoption of the report by the other twenty-seven members of the OECD).

The OECD makes a useful distinction between tax competition in the form of generally applicable lower tax rates, and tax regimes designed to attract foreign investors. This distinction is both normatively and pragmatically sound: restricting tax competition should not and cannot mean that voters in democratic countries lose their right to determine the size of the public sector through general tax increases or reductions. Rather, it means that countries should not provide windfalls for foreign investors at the expense of the ability of other countries to provide those public services their residents desire. Such limitations are particularly appropriate because those foreign investors themselves often reside in countries providing a high level of services, and yet refuse to pay the tax price that providing such services entails.

Still, relying on the OECD to restrict tax competition suffers from three significant drawbacks. First, the OECD only has twenty-nine members, and it is not clear that it can effectively enforce its anti-tax competition rules on non-member countries. For example, solutions that rely on where the parents of Multinational Enterprises (MNEs) are located assume that no significant growth in MNEs will take place outside the OECD, and solutions that rely on the OECD as the market assume no significant markets outside the OECD. Either assumption may become wrong, and when that happens, solutions that rely on OECD enforcement will lose their effectiveness unless those emerging markets were to join the OECD. While several developing countries have joined the OECD recently (e.g., South Korea and Mexico), it is hard to imagine China or India doing so in the near future.

Second, relying on the OECD to implement solutions to the tax competition problem, even if those solutions are tailored to benefit developing countries, may not be acceptable to those countries. Even though the OECD has made a huge effort to include non-OECD members in the tax competition project, it is still identified as the rich countries' 
club. Thus, it is hard to believe that developing countries will be able to shed their suspicion that the OECD will not act in their interests, even if it can actually be made to do so. In fact, the effort by the OECD to develop a multilateral agreement on investments (MAI) foundered precisely because developing countries and left-leaning non-governmental organizations coordinated a campaign against it as representing the interests of the rich countries and "their" MNEs.

Third, the OECD effort is limited, so far, to geographically mobile financial services, and excludes real investments, although these constitute a significant part of the problem. In addition, even for the areas it does cover, the OECD has only the power to persuade, not to adjudicate.

From these perspectives, the World Trade Organization (WTO) is a more attractive candidate for "world tax organization." It has a much broader membership than the OECD, and developing countries are much better represented (and have real clout, as shown by the recent struggle over choosing the Director General of WTO). Moreover, as indicated above, the WTO rules already cover and prohibit most forms of harmful tax competition identified by the OECD.

There are, however, several serious objections to including tax matters in the jurisdiction of the WTO. First, it has been argued that the WTO lacks sufficient tax expertise. That problem, however, can be remedied by hiring a sufficient number of tax experts to sit on the WTO's panels. In fact, as the WTO has expanded its jurisdiction to non-tariff matters, its staff already includes tax experts who also understand trade issues.

Robert Green has advanced a more serious objection, arguing that the costs of imposing the WTO's legalistic dispute-resolution mechanism outweigh any benefits. ${ }^{46}$ Green argues that the need for the WTO to resolve trade disputes legalistically is based on two features that are typically lacking in the tax context: retaliation and lack of transparency. Retaliation is a feature of repeated prisoners' dilemma type games and insures that players have an incentive to cooperate. In an assurance (stag hunt) game, both players cooperate if they can be assured of the other player's cooperation. In the first case an organizational setting is needed to manage retaliatory strategies, while in the second it is needed to provide the information needed for the assurance to exist.

In the context of tax competition, though, it would seem that both retaliation and lack of information are serious problems. For example, in the case of portfolio investment, the United States began a race to the

46. Robert A. Green, Antilegalistic Approaches to Resolving Disputes Between Governments: A Comparison of the International Tax and Trade Regimes, 23 YALE J. INT'L L. 79, 129-39 (1998). 
bottom by abolishing its withholding tax, and other countries responded (i.e., retaliated) by abolishing their own taxes. In the current situation, no country dares re-impose its tax without adequate assurance that other countries will follow. Similarly, for direct investment, countries have adopted tax incentives or deferral and exemption rules for their resident MNEs in response to the actions of other countries, and fear changing such policies without assurance that others will follow suit. Thus, whether these developments are characterized as prisoners' dilemma or assurance games, they seem to present precisely the kind of problem that only a multilateral organization with rule-making power can effectively resolve.

Green also raises another objection to giving the WTO authority over taxes, which in practice is likely to be far more potent: the problem of sovereignty. ${ }^{47}$ Countries are wary of giving up their sovereignty over tax matters, which lies at the heart of their ability to exercise national power. This concern is particularly acute in the United States and almost led to the failure of the entire Uruguay Round, as the United States insisted at the last minute on excluding direct taxes from the purview of the GATS. Green argues that if the WTO dispute resolution mechanism were given authority over tax issues, this may lead to widespread noncompliance, especially given the perception that the WTO is nontransparent and lacks democratic legitimacy.

Green may be wrong about this estimate, especially since the analysis above has shown that the WTO already has jurisdiction over most forms of harmful tax competition, so that no further extension of its powers is necessary. But even if Green is right and sovereignty poses a real problem, there may be a solution to this as well. Under the GATT regime, all decisions had to be reached by consensus, that is with the agreement of the party whose regime is at stake. Under the WTO rules, on the other hand, all dispute settlement rulings are binding unless there is a consensus not to implement them; that is, unless even the complaining party agrees to refrain from action. Perhaps the former rule is more appropriate for tax matters than the latter, because it gives the loser a veto if it feels that its sovereignty is truly at stake. Similar rules exist for tax matters in both the EU and the OECD. But, as the DISC case in the $\mathrm{GATT}^{48}$ and the adoption of the tax competition report by the OECD

48. The DISC case was brought by the European Union against the United States under the old GATT regime, challenging the Domestic International Sales Corporation (DISC) as an export subsidy. The United States lost and complied by abolishing DISC, even though it could have vetoed the panel report. But see Yong K. Kim, The Beginnings of the Rule of Law in the International Trade System Despite U.S. Constitutional Constraints, 17 MiCH. J. INT'L L. 967, 980 n.64 (1996)(describing U.S. heel-dragging regarding adoption of the report). 
show, a country will typically reserve its veto power for those cases in which the adverse result is truly perceived as a severe limit on its sovereignty. In other cases, the stigma of disapproval is sufficient to ensure cooperation.

Thus, in the final analysis, it may be necessary to set up a multilateral organization with different rules than the WTO, but with similarly broad membership. The UN is the obvious venue for setting up such an organization, building on the important work of the League of Nations Fiscal Committee. The Current Ad Hoc Group of Experts on International Cooperation in Tax Matters should be upgraded to provide the basis for such an organization.

\section{Conclusion}

As a result of globalization and tax competition, tax rules can no longer be set by countries acting unilaterally or by bilateral tax treaties. In a world in which capital can move freely across national borders and multinationals are free to choose among many investment locations, the ability of any one country (or any two countries in cooperation) to tax (or otherwise regulate) such capital is severely limited. Any such unilateral attempt will be undercut by other countries, and will probably not even be attempted, in the name of preserving national competitiveness. Thus, a multilateral solution is essential if the fundamental goals of taxation or other regulation are to be preserved. Private market activities that span the globe can only be regulated or taxed by organizations with a similar global reach.

This paper has attempted to outline some of the ways in which such global governance can be achieved in the area of capital income taxation. Achieving this goal will not be easy, given the expected resistance of both private actors eager to preserve their freedom from taxation, and of governments concerned about preserving their sovereign ability to set their own tax rules. But it is not impossible. Moreover, because preserving the ability of developing nations to tax income from capital is essential to the achievement of the Millennium Development Goals, it must be tried. 